\title{
"As parents congregated at parties": Responsibility and blame in media representations of violence and school closure in an Indigenous community
}

\author{
This article considers the discourses of responsibility and blame emerging from \\ newspaper reportage of a crisis in the remote Indigenous community of Aurukun in \\ Northern Queensland, Australia. In doing so, it aims to contribute to the sociology of \\ racism and add to the existing body of scholarship on the ways in which deracialised \\ discourse media discourse can nevertheless be racist. The month of May 2016 saw \\ violence perpetrated by young people against the teachers and principal of the \\ community's only school. Teachers were evacuated to the regional city of Cairns in on \\ the 10th due to violence in the community and fears for their safety. They returned on \\ the 18th, only to be evacuated again on 25 May. These events form the focus of the \\ reportage analysed in this article. The way in which three primary groups of players - \\ parents, teachers, and police - are portrayed in mainstream print media is analysed in \\ order to ascertain how responsibility and blame are apportioned in relation to these \\ events.
}

Keywords: Indigenous Australian; school closure; media discourse; Aurukun; parents; critical discourse analysis

\section{Introduction}

This article deals with discourses of responsibility and blame emerging from newspaper reportage of a crisis in Aurukun, a remote Indigenous community in Northern Queensland, Australia. In doing so, it aims to contribute to the sociology of racism and add to the existing body of scholarship on the ways in which deracialised discourse media discourse can nevertheless be racist. May 2016 saw violence perpetrated by young people, allegedly including children as young as six, against the teachers and principal of the community's only school. Teachers were evacuated from Aurukun to the regional city of Cairns in on May 10 after fears for their safety arose. They returned on the 18th and were evacuated again a week later. These events form the focus of the reportage analysed in this article. The way in which three primary groups of players - parents, teachers, and police - are portrayed in mainstream newspapers is analysed in order to ascertain how responsibility and blame are apportioned in relation to these events. The representation of young people is not a primary focus of analysis. This is intentional: the focus of this article is on blame directed at parties other than the offenders. 
It is important to note, as a precursor to the analysis in this article, that I am not an Indigenous person. I make every effort to write respectfully and to highlight dominant discourses relating to Indigenous people in a way that is critical, reflexive, and aware of the cultural and historical experiences behind the events in Aurukun. As a white Australian of British heritage, however, I acknowledge that I write from a position of privilege and do not have personal experience of life as an Indigenous person. I state my position here because I believe that it is important, in conducting critical discourse analysis, to be upfront about one's biases, insights, and limitations.

\section{Context}

Aurukun is an Indigenous community in Far-North Queensland. Slater states that Aurukun has received 'more than its fair share' of negative media attention (2008: 1). She notes that the Wik native title case, which first drew attention to the people of Aurukun, has been overshadowed by narratives of dysfunction. These have been associated with policies intended to combat Indigenous disadvantage such as the 2008 Cape York Welfare Reform Trial which would eventually become a permanent part of the welfare system in the region (Smyth, 2011: 14). Significant negative events have also formed a vital part of the media narrative. One such event was the 'Aurukun rape case', which dealt with the repeated rape of a 10-year-old-girl by seven juveniles and two adults over a two-month period in 2006. This case made news throughout Australia and internationally (Storr, 2009: 107). Media representations of the case were primarily focused on the outcome, in which the juveniles received 12 months' probation while the adults each received a six month suspended sentence. The sentences, and controversy over an expose published by The Australian, became the story. The abuse itself was largely ignored in this reportage. In 2008 these sentences were overturned by the Queensland Court of Appeals, with five of the offenders sentenced to terms in prison from 3-6 years (2009: 107-108). Storr argues that these original sentences resulted from a legal system which views Aboriginal communities as chronically dysfunctional (2009: 109). According to Due and Riggs, this incident was used to justify the Northern Territory Intervention. The discourse of protection media and political descriptions of the event and the Intervention at times 'appeared to foreclose any possibility of debate as to the appropriateness of the 'intervention' in mainstream media' (2012: 5). Indigenous communities, particularly Aurukun were positioned as violent and out of control with Indigenous children passive victims (2012: 8-9).

All of this negative coverage overshadows positive stories which emerge from Aurukun and the ways in which members of the community speak back to negative representations. Slater writes of the Aurukun Student Storytelling Project in which students were assisted, by a group called Community Prophets, to use film to tell their own stories. These children were aware of the way their community is represented and sought to contest that by produce their own images of themselves as creative, happy, people. Such events challenge perceptions of Indigenous children living in Aurukun as mere victims and re-present them as people with their own nuanced identities and life stories (2008: 11).

\section{Literature Review}


This section deals with the sociology of race and racism in Australia as it relates to media discourses. Particular attention is paid to research focusing on portrayals Indigenous disadvantage and the intersection between race and criminality. Overwhelmingly, the research suggests that Indigenous Australians are positioned in media discourses as disadvantaged and dysfunctional. Howard-Wagner argues that this positioning allows for the governance of Indigenous peoples through disadvantage, 'a complex, overt racial project in which Aboriginal and Torres Strait Islander peoples are invented, constituted and assimilated into the neo-liberal body politic through the positive paternalistic governing of their socio-economic disadvantage' (2017: 4). The focus on disadvantage leads to the discussion of traditional lifestyles in terms of economic viability with Indigenous homelands and cultures being viewed as unviable (2017: 12-13). Further, poverty becomes associated with passivity and dysfunction, justifying paternalistic state intervention (2017: 13). In relation to education, Hogarth (2017) uses Indigenous Critical Discourse Analysis to demonstrate that the attainment of Aboriginal and Torres Strait Islander students is often positioned through the discourse of deficit. Aboriginal and Torres Strait Islander parents are discursively positioned as unable, through a deficit of education, to contribute to the education of their children (2017: 32). Slater (2010) questions the frequent positioning of Indigeneity as deficient or disadvantaged, stating that while such discourses make disadvantage evident to mainstream Australians they also serve to limit and prevent engagement with the lived experience of Indigeneity

Critical discourse analysis has also been used to demonstrate the way in which 'new racism' emerges in relation to media narratives about race and crime. Peter Teo begins his 2000 analysis on representations of a Vietnamese gang in Australian newspapers by stating that:

The subject of this study is 'racism'. But it is not racism of the sort that is overt and often violent, involving verbal or even physical abuse on the ethnic group that is being victimized. [...] That is old racism (2000: 7).

He continues, stating that there is a form of 'new racism' which is more subtle and which can be traced in newspaper discourse in modern societies (2000: 8). This accords with the findings of Poynting and Noble (2003) who examine media discourses relating to Muslim Australians and find that 'dog whistling', or implicitly sending negative messages or inciting negative responses is a common and irresponsible feature of such reportage. Augoustinos and Every, using critical discourse analysis and discursive psychology to examine the way race is discussed in Australia, indicate that contemporary racist discourses often include attempts to deracialise negative perceptions of minority groups (2007: 133).

Howard Sercombe (1995) demonstrates the way in which racist discourses which connect Aboriginality and criminality can emerge in news media without ill-intent or apparent bias. He conducted an analysis of all articles published from April 1990 to March 1992 in the general news pages of the West Australian relating to young people. Direct references to Aboriginality occurred in ten percent of these articles, outnumbering the next most common racial reference point ten to one. Aboriginality is, Sercombe indicates, used as a marker or label which 'makes sense' of action. That almost 85 per cent of these articles were about crime suggests that Aboriginality is viewed as an explanatory factor in criminal deviance (1995: 77-78). Sercombe does not suggest that the newspaper itself is racist: instead, he indicates, it is dependent upon the police and courts for news. 
The worldview presented has less to do with any editorial intention on the part of the newspaper and its staff and more to do with the sources upon which it depends. Crime is a common source of newsworthy material and, as Sercombe notes, the overrepresentation of Aboriginal young people in the criminal and justice system leads to a concentration of news about Aboriginal young people into crime news (1995: 89). Nevertheless, he writes, the enduring presence of this form of news speaks to a desire among the newspaper's audience to read it. He associates this desire with a displacement of fear 'onto some other' (1995: 92). This accords with the findings of Poynting et al (2001), who examine the media framing of 'ethnic gangs' in south-west Sydney between 1998-2000 finding that the media, alongside politicians, community leaders, police, and others, created a racialized Other which criminalised Lebanese-Australians (2001: 72).

Public discussions about negative child behaviour often focus on parents. Herne argues that research relating to school bullying often focuses on the causes of bullying and that the responsibility of parents for poor child behaviour is at the heart of these discussions (2016: 643). Previous researchers have pointed out that mothers generally bear the burden of blame and work associated with children's troubles in education, including disciplinary troubles (e.g. Dudley-Marling, 2001). There is thus a gendered aspect to the blame associated with poor child behaviour. This is an important element to the reportage of the incidents in Aurukun.

\section{Methodology}

Critical discourse analysis (CDA) is concerned with the relationship between texts and social processes (Carvalho, 2008: 162). It aims to go beyond describing discourse, to consider how and why discourses emerge (Teo, 2000: 11). CDA also requires the analyst to unpack the naturalised ideologies which underpin discourse and which often go unquestioned (Teo, 2000: 12). This was selected as an appropriate methodology through which to analyse the newspaper coverage of the school closures in Aurukun due to its potential to bring into question the power structures and ideologies that lie behind public discussion of Indigenous struggles.

Data were obtained from Factiva, an international news database. All news articles from May 2016, the month in which both evacuations occurred, from Queensland newspapers relating to the search term 'Aurukun' were obtained. Those relating to the highly public incidents involving the staff at the Aurukun school were saved. Seventy news articles were deemed relevant for inclusion in this analysis. These articles all relate in some way to the violent incidents which precipitated the removal of teachers from the remote community on two occasions and on the discussions and planning occurring in the wake of these incidents. The data consist of both hard and soft news, containing opinion pieces, letters to the editor, and vox pops alongside standard news articles. All of the data come from three newspapers, The Courier Mail, the Cairns Post, and the Townsville Bulletin. These newspapers are all owned by NewsCorp. The relative lack of diversity is due, largely, to an actual lack of diversity in Queensland news ownership. Carvalho indicates that most studies of media discourse cover a relatively limited period of time and that, while this is relevant to some issues, it fails to take into account the historical context of media discourse (2008: 164). This paper analyses only one month worth of data, but it does so for a period which may fairly be described as a critical discourse moment: a moment at which established discursive positions are brought into question (Carvalho, 2008: 167). The dataset consists of mainstream commercial reportage. Different 
discursive formulations may exist in coverage on the national broadcaster, free online media sources such as The Guardian Australia, and particularly in Indigenous media.

Data were initially analysed using TAMS Analyzer. This is an open-source qualitative analysis tool which allows data to be hierarchically coded and compared. Dominant themes were identified and coded. The coded data was then re-analysed and the dataset re-coded. During recoding the focus was on power: the way in which existing power structures justified or undermined by language - and how particular words, phrases, or journalistic choices have contributed to this. Two types of coding were used. The first identified the groups discussed in the article. The most common of these were 'parents', 'teachers', 'children/students', 'young offenders', 'politicians', and 'police officers'. The second set of codes identified key themes. These included 'community breakdown', 'crime'. 'evacuation', 'responsibility', 'failure', 'fear', 'Indigenous disadvantage', 'duty', 'heroism', and 'law and order'. The following discussion deals with the interplay between these two sets of codes and the results for the framing of key stakeholders in the media coverage. Selected extracts are provided to highlight the discursive formations evident in the dataset.

\section{Discussion}

In the midst of the crisis newspaper articles did the work of apportioning blame. The discourse of community breakdown permeates the dataset. Much of the reportage is concerned with the question of what went wrong to allow the community to reach breaking point. The discourse of community breakdown is thus interconnected with the apportionment of blame. A 703 word opinion piece published in the news section of the Cairns Post on 12 May 2016 with the title Time to stop excusing thugs is an extreme example of the discourses of blame and community breakdown in action.

WHAT'S wrong with this picture?

Teachers are forced to evacuate Aurukun as thugs armed with axes go on a rampage. But instead of decrying the violence and sending in some hard-hitting riot police, there are calls for the State Government to build "safe spaces" for teachers to retreat to when the locals decide it's time to arm themselves and rise up against their so-called oppressors.

The truth is, mainstream Australians are getting sick of being told they are somehow responsible for the lawlessness, unemployment, substance abuse and violence in remote indigenous communities, rather than the actual offenders (Tomlinson, 2016b: 14).

Here blame is apportioned between the State Government and the Indigenous offenders in Aurukun. The State Government is treating violence softly by failing to 'send[...] in some hard-hitting riot police' - although in fact additional police were sent to the community and there is no indication that a riot had occurred - and the young offenders, described as 'thugs', are 'on a rampage'. The use 
of the term 'thug' to describe disengaged teenagers is loaded. It is important to note that it is not merely these young people, but 'the locals' who are positioned as 'ris[ing] up' against the teachers and principal of Aurukun. 'Locals' is a broad term, potentially encompassing all residents of the community. The 'so-called oppressors' are associated not just with the teachers who have been the victims of attacks but also, by proximity within the article, with 'mainstream Australians': that is, non-Indigenous Australians.

The author makes explicit his belief as to who should be held responsible later in the article. He uses the word 'apologists' as a descriptor for persons who view the violence and other community issues as rooted in a history of disadvantage and oppression. 'Apologists', in this extract, naively ignore the reality that some individuals make negative choices with a detrimental impact on law and order.

Apologists for the Aurukun thuggery say the problems are caused by lack of jobs, boredom and racism-inspired substance abuse.

Another reason given is that government policy forced warring tribes to live together in the town many years ago, so it's the Government's fault that murderous and terrifying street violence takes place.

Again, no real blame is placed on those who drink too much, torch cars, threaten innocent people and go on violent rampages (Tomlinson, 2016b: 14).

The tendency to ascribe responsibility or blame to individuals or groups is a defining feature of this corpus. Of the 70 articles analysed, 33 contain a reference to responsibility. The Cairns Post article quoted earlier in this section states that 'first and foremost, indigenous leaders need to demand their people make better lifestyle decisions' (Tomlinson, 2016b: 14). The onus is thus placed on Indigenous leaders to control Indigenous offenders. The term 'lifestyle decisions' is an important one. By describing alcohol abuse, violence, and other criminal behaviours as 'lifestyle decisions' the author both minimises the impact of these issues and dismisses the impact of historical and social inequality on the life choices available to Indigenous people living in remote communities. Responsibility thus becomes individual responsibility and community responsibility: Indigenous elders are positioned as responsible for the actions of members of their communities, while individual Indigenous people are responsible for their choices. Responsibility is not, notably, held by the wider society in relation to Indigenous people. Instead, non-Indigenous people are seen as being made, unfairly, to assist in responding to crises which are the result of Indigenous failure to act responsibly. Competing conceptions of who, or what, is to blame for the events leading to the two school closures - and of who has failed to fulfil their responsibilities - form the focus of the analysis which follows. Three groups - parents, teachers, and police, are analysed in relation to the way they are discursively positioned and the extent to which they are viewed as holding, using, and failing to maintain power and control over the situation.

\section{Parents}


The parents of Aurukun are overwhelmingly portrayed as failing to fulfil their responsibility to care for their children. Twenty-eight of the 70 articles analysed contain a reference to parents. The discourse of parental failure is employed as a means of explaining the disrupture occurring in the town. This discourse is used in a way which attributes power over child behaviour to parents. Parents are seen as either abdicating this power or failing to use it correctly. One article published in the news section of the Courier Mail on the $29^{\text {th }}$ of May, entitled RIVERS OF GROG, DESPAIR, and attributed to PETER MICHAEL IN AURUKUN makes the case for parental failure as a cause of youth problems through referring to the journalist's personal observations:

Despite a mosquito plague, scores of semi-clad young children ran through the streets late into the night as parents congregated at parties just hours after the Premier and cabinet ministers flew out after crisis talks (Michael, 2016: 15).

This article, published at the end of the selected month, is demonstrative of the construction of the discourse of parental failure through the dataset. The title of the article leaves little doubt as to the way in which Peter Michael's observations are to be read. In the context of an article with the title RIVERS OF GROG, DESPAIR, the statement that 'parents congregated at parties' implies that parents were ignoring their young children in order to consume alcohol. The description of 'scores of semiclad young children' who 'ran through the streets late into the night' during a 'mosquito plague' is one which implies serious parental neglect. The statement that this occurred 'just hours after the Premier and cabinet ministers flew out after crisis talks' clearly indicates the journalist's perception that the parents are, if not themselves directly responsible for the crisis, at least engaging in behaviours which contributed to its development. Other potential readings for the observations of the journalist are ignored. The idea that parents could be congregating to speak about the events and the crisis meetings, or that they could be engaging in socialisation necessary for continued community cohesion, is ignored. The idea that groups of children could be 'semi-clad' in response to heat, and that they could be playing together as members of a community, observed by adults working in co-operation with one another, is abandoned. The reading this journalist provides of the events he witnessed makes sense in the context of dominant discourses of community breakdown and parental failure. That no other possible reading is offered is evidence of the power of these discourses.

Importantly, members of the Aurukun community, where they are given a voice in news reports, accord with this reading of the Indigenous parents in Aurukun as irresponsible and as neglecting their children. Aurukun's Mayor, Dereck Walpo, is quoted in several articles as blaming parents for community disruption. The two extracts below show two of the ways in which his words are used to justify the blame of Indigenous parents:

Extract 1: At yesterday's community meeting, Mayor Dereck Walpo told the crowd they should be ashamed of themselves for failing to take responsibility for their children. “We, as a community, aren't playing our part. No one seems to know where their kids are after $6 \mathrm{pm}, "$ he said. 
"It's more than a lack of respect and a lack of discipline. This is neglect" (Vogler and McKenna, 2016b: 30).

Extract 2: Mr Walpo said families of offending children repeatedly failed to show at community meetings about the ongoing violence but still accepted Government handouts (Cairns Post, 2016: 3).

In extract one Walpo's statement is directed at the community as a whole. The word 'we' is used, suggesting a shared sense of responsibility for parental failure. 'No one' seems to know where their children are. The discourse of parental failure is employed here in order to suggest a problem with the community. Despite being attributed to an elected Aboriginal leader, this statement speaks to underlying assumptions as to the inability of Indigenous people to manage child behaviour. Extract two is less generalised and more pointed. Here Walpo is indirectly quoted as referring specifically to the families of those children involved in the 'ongoing violence'. These parents are positioned as failures due to not attending community meetings relating to the crisis in the community. This is juxtaposed with their willingness to receive 'government handouts'. Here Indigenous parents are positioned as disconnected and dependant on welfare. The selection of these quotes is used by journalists to demonstrate that negative perceptions of Indigenous Australians are shared by Indigenous Australians themselves. This serves to remove whiteness from the equation, removing this discourse of Indigenous deficit from the context of racialized disadvantage and oppression and rendering it acceptable.

Other articles employ the discourse of failed parenting in connection with the discourse of community breakdown. The effect of these articles is to suggest that, in a community in which law and order is in trouble, Indigenous parents need to do additional labour in order to prevent their children from engaging in criminal behaviours. The two extracts below represent two ways in which this suggestion is made:

Extract 1 "Satellite" parenting, where kids dictate to parents how they'll be raised, is endemic across all Australian society and it's resulting in a total lack of respect for any authority. This lack of respect rarely makes headlines or causes planeloads of politicians to fly in to see what's going on for themselves, but it does in Aurukun (Tomlinson, 2016a: 36).

Extract 2 The reality behind the violence is that a group of parents in the settlement will not take responsibility for their children - children who often believe their one chance of obtaining any real status within their community rests largely on obtaining a criminal conviction and a jail term (Madigan, 2016: 41).

Extract one suggests that the problems faced in Aurukun are the result of parenting problems that are faced throughout Australia. The word 'dictate' in the phrase 'kids dictate to parents how they'll be raised' is used to indicate that parents entirely abdicate their responsibility and allow their authority to be usurped by their charges. The special circumstance in Aurukun is not that parents act 
in this way, but instead that the actions of their children are so extreme as to create a crisis. Extract two similarly refers to the extremity of Aurukun as a case of child misbehaviour, but more explicitly points to the perceived desirability of criminality among Indigenous youth - a stereotype which goes unquestioned.

\section{Teachers}

Of the 70 articles analysed, 43 explicitly discuss teachers. The news articles in the dataset reveal that the teachers of Aurukun are housed in a fenced compound separate to other community members (Geiger, 2016: 3; Geiger and Vogler, 2016: 15). Teachers are overwhelmingly portrayed as powerless in the face of violence and disruption. As such they become positioned as innocent and helpless victims rather than as social actors with their own autonomy. Teachers are therefore largely insulated from blame in relation to the community violence and the school closures resulting from their decision to evacuate Aurukun. Discourses relating to teachers are primarily those of fear and safety. A news article in The Courier Mail published on 11 May and dealing with the initial evacuation of the school set the tone for reportage of the crisis. The following extract is demonstrative:

A CAPE York school of 200 students has been temporarily shut down and extra police rushed to the town to deal with unrest as more than 20 teachers were ordered to evacuate yesterday amid fears for their safety.

Education Minister Kate Jones said she was deeply concerned for the safety of teachers at the Aurukun campus of the Cape York Aboriginal Australian Academy and promised the department would review its infrastructure and security in the town immediately. Five extra police were sent in as reinforcements yesterday following a weekend incident in which the school's principal was allegedly threatened with an axe and his car stolen by a group of males aged under 19 .

It was the tipping point for a union meeting of teaching staff on Monday night in which they expressed fear and called for their removal from the community on full pay while a safety strategy was negotiated (McKenna, 2016b: 6).

This article is a straight news piece. It sets up the themes of safety and fear associated with teachers. It also employs the term 'tipping point', suggesting that teachers have been suffering improper conditions for some time. While the closure of the school is the ostensible subject of the article, the fears of the teachers occupy most of the column space. Provisions for the children attending the school are not mentioned. A brief opinion piece published on the same day and in the same newspaper entitled Staff safety must come first emphasises this prioritisation of teachers over Indigenous children: 
In Aurukun, where teachers are worried about personal safety and are now being moved, there has been unrest for some time - a situation which is far from exclusive to this town. Any review of Aurukun should perhaps be also extended to similar communities. Safety must be paramount wherever our public servants are on the frontline, both for their own wellbeing and the long-term health of the local community (The Courier Mail, 2016: 28).

Readers are encouraged, through the discourses of fear and safety, to empathise with the teachers who were evacuated. They are also encouraged, in this and subsequent articles, to view Aurukun as a frightening place for teachers.

Extract 1: SHAKEN teachers say they are too scared to return to the troubled Western Cape York community of Aurukun.

Those who do return will have "screamer" security alarms, which emit loud noises and flashing lights when triggered, installed in their homes and improved fencing around their accommodation.

Queensland Teachers Union president Kevin Bates said the few members who did not want to go back to Aurukun following the recent threats and strife would be deployed elsewhere. (Geiger and Vogler, 2016: 15).

Extract 2: Twenty-five teachers left the community after the first incident and only returned last week. Five chose not to return.

Teachers have decided to remain in Aurukun for now but Queensland Teachers' Union president Kevin Bates said any further incidents could force staff to leave the remote community.

"I think we are on the threshold right now," he said (Chamberlain and Templeton, 2016: 9).

Extract one comes from an article entitled Too scared to go to school published on 18 May 2016 in the Courier Mail. While the title indicates that teachers were loath to return to Aurukun due to fears for their safety, the body of the article notes that the majority of teachers did choose to return. The discourse of fear was again employed after teachers returned to the community. Extract 2, from an article entitled Security fears for Aurukun teachers, is representative of news articles relating to concerns for the safety of teachers after their return.

\section{Police}

Of the 70 articles analysed, 41 contain a direct reference to police. References to police are 
connected to discursive constructions of community breakdown and failure of law and order. Police are positioned as people with the power to assist in preventing the worsening of the situation, or as people who have failed in their responsibility to maintain control in the community. Unlike parents, who are primarily positioned as blameable figures, or teachers, who were positioned as innocent victims, the portrayal of police is more ambivalent.

Police are represented both as a potential salve for the crisis ('Five extra police were yesterday sent to help control the situation' (McKenna, 2016c: 3) and as failing to competently carry out their responsibilities ('TEACHERS were forced to wait more than half an hour after calling police for help in the remote community of Aurukun' (Vogler and McKenna, 2016a: 7). The discourse of failure and blame in relation to police is most evident in articles relating to the views of Indigenous women. The Wik women of Aurukun, members of one of the Indigenous groups brought together when the community was a Lutheran Mission, are the only group of Aurukun Aboriginal people given a meaningful opportunity to speak within the corpus. The two extracts below show the way the views of this group were used in news texts.

Extract 1: Nowhere else in Australia would a government condone shutting a school due to the incompetence of police, who have been unable to pull into line a handful of troublemakers. Solving a problem with 15 disengaged youths by disengaging another 300 children from school is a recipe for disaster.

Today in Aurukun, teachers were refusing to leave, they were crying at the thought of the school and its children being abandoned. For too long police have turned a blind eye to sly grog. They have set a climate for lawlessness. Police need to do their job. This is a policing problem and we need a policing solution (WIK WOMEN'S GROUP MOTHERS, 2016: 5)

Extract 2: THE Wik women of Aurukun say they want the same standard of policing of violence as elsewhere in the state.

As Minister for Aboriginal and Torres Strait Islander Partnerships Curtis Pitt travels to the township today in the wake of recent unrest, a female elder claims authorities have been turning a blind eye to violence, allowing a culture to fester in which youths "think they can get away with it".

In an email to the Police Minister and Commissioner in March, a group of local women raised concerns and urged police to enforce a zero tolerance approach to fighting.

"On behalf of women and children we insist that the QPS enforces a zero tolerance to fighting and 'punching' as does the rest of our state with its one-punch law," they wrote (McKenna, 2016a: 11)

Extract one comes from an opinion piece published in the Courier Mail on 26 May 2016 entitled Ineptitude of police is depriving achievers. The article is attributed to the mothers of the Wik 
women's group. Extract two is a news article published in the Courier Mail and attributed to a journalist. The views of the Wik women are represented through quotes. In both pieces the view of this group that police are failing in their duty to the community is clear. In the first extract the school has been shut 'due to the incompetence of the police' who have 'turned a blind eye to sly grog' and who 'need to do their job'.

Police are also represented as good people doing their best in a difficult situation. This discourse of heroic police serves as a counter-discourse to the discourse of police failure put forward by the Wik women, among others. Police sources are used to justify this discourse as seen in the following extracts:

Extract 1: Commissioner Taylor was blunt in his message to the community. "Coppers don't want to go out and arrest people for carrying grog, having drugs, or weapons," he said. “Just the same as nurses don't want to treat people that are affected by alcohol, have been bashed because people have been drunk or stabbed because of fights where people are affected by drugs or alcohol" (Radke, 2016: 8)

Extract 2: Queensland Police, tired of the generational cycle of convictions and jail, say the state can't arrest its way out of Aboriginal disadvantage.

Police presence in Aurukun has been at extraordinary levels for decades. There are usually about 13 police for a settlement of about 1300 people while a small town with an equivalent population in another part of Queensland would be served by a twoofficer station.

But policing a place like that requires a different set of skills to policing an indigenous community. Queensland still has the drunk and disorderly charge on the books and police would not hesitate to throw a drunk in the watch-house for a few hours to sober up.

But putting an indigenous teenager affected by alcohol in a watch-house is precisely what the Royal Commission into Deaths in Custody, which released its findings 25 years ago, was designed to prevent.

Queensland Police Union president lan Leavers [...] says police try to avoid incarcerating indigenous people for minor offences. "That is the last option. Police would much prefer to be able to take a person who is intoxicated or just causing trouble home to their families," Leavers says.

"Police are doing an outstanding job under difficult and sometimes dangerous conditions. This is not an issue of policing in itself. This is a matter of people needing to take responsibility for themselves and their dependants and we need greater engagement from government agencies both state and federal." (Madigan, 2016: 41). 
The first extract, from the Cairns Post, uses a police source to invoke the discourse of duty. Police officers are portrayed as responsible, fulfilling their duty in extremely difficult circumstances. The blame is then placed on members of the community for forcing them into such circumstances. The second extract is from the Courier Mail. It uses a source from the Police Union to invoke the discourse of heroism. Police are 'doing an outstanding job' under circumstances which are 'difficult and dangerous' - these circumstances being the result of behaviours in Indigenous communities.

\section{Further Discussion}

This episode represents a critical discourse moment in Carvalho's sense (2008: 167). During this period established discursive positions - those relating to the positions and responsibilities of police, teachers, and parents in relation to Indigenous schools and communities - were alternatively solidified and drawn into question. The ability of the Wik women's group in particular to make their voices heard in the media coverage of this event allowed them to challenge the heroic discursive representation of police. At the same time, negative discursive representations of Indigenous Australians - particularly representations relating to parental failure - were reiterated and further solidified. The positioning of teachers as victims contributed to discursive constructions of Aboriginal people as violent or threatening.

This study supports Sercombe's (1995) finding that racist discourses in news media can arise without any apparent bias or ill intent on the part of journalists or media owners. The events in Aurukun during this period were dramatic and inherently newsworthy. The media discourses were largely shaped by the comments of sources, some of whom, like Mayor Dereck Walpo, made damning comments about the community. The racism evident in the media discourses analysed in this paper is the 'new racism' described, for example, by Teo (2000: 8), a type of racism which, as Augoustinos and Every have stated, deracialises negative understandings of minority groups (2007: 133). Negative characteristics are associated with parental failure, alcohol abuse, or community breakdown. In most cases the assumption that these issues are associated with Indigeneity are not explicitly stated.

\section{Conclusion}

The discourses analysed in this paper are largely deracialised. They do not explicitly position Indigeneity as the factor resulting in the crisis in Aurukun. As this paper has shown, however, these deracialised discourses are themselves racist, positioning this Indigenous community as a failed community with inept parents leading to the criminalisation of youth. By examining the discourses relating to parents, teachers, and police I have attempted to demonstrate that blame for this event has largely been attributed to Indigenous parents, who are spoken about in relation to discourses of deficit and failure. In doing so, I add to existing sociological understandings of race and deracialised racist discourse. The data presented here also suggest that certain Indigenous people - in this case the Wik women's group - have the ability to question dominant discourses of blame and ascribe responsibility for crisis elsewhere. This does not, however, represent an ability to refute racist media discourses in any systematic way. I have no desire, in writing this article, to suggest that any of the 
groups under discussion here - parents, teachers, and police - are in any way to blame for the crisis in Aurukun. Indeed, I would suggest that the notion of blame is itself problematic and does little to address the future needs of the community. Instead, I aim to present evidence of the way in which long-held prejudice and unequal power structures are justified through discourse in this reportage. This has greater implications. Future research may focus more specifically on the differences in discursive representations of Indigenous and non-Indigenous parents in critical discourse moments relating to child behaviour. 


\section{Reference List}

Augoustinos M and Every D (2007) The Language of 'Race' and Prejudice: A Discourse of Denial, Reason, and Liberal-Practical Politics. Journal of Language and Social Psychology 26(2): 123141.

Cairns Post (2016) Mayor wants difficult kids removed. Cairns, 23rd May.

Carvalho A (2008) MEDIA(TED) DISCOURSE AND SOCIETY: Rethinking the framework of Critical Discourse Analysis. Journalism Studies 9(2): 161-177.

Chamberlain T and Templeton A (2016) Security fear for Aurukun teachers. The Courier Mail, Brisbane, 23rd May.

Dudley-Marling C (2001) School Trouble: A mother's burden. Gender and Education 13(2): 183-197.

Due $C$ and Riggs DW (2012) THE TERMS ON WHICH CHILD ABUSE IS MADE TO MATTER: Media Representations of the Aurukun Case. Australian Feminist Studies 27(71): 3-18.

Geiger D (2016) Alarms to ease teacher worries. Cairns Post, Cairns, 18th May.

Geiger D and Vogler S (2016) Too scared to go to school. The Courier Mail, Brisbane, 18th May.

Herne KE (2016) 'It's the parents': re-presenting parents in school bullying research. Critical Studies in Education 57(2): 254-270.

Hogarth M (2017) Speaking back to the deficit discourses: a theoretical and methodological approach. The Australian Educational Researcher 44(1): 21-34.

Howard-Wagner D (2017) Governance of indigenous policy in the neo-liberal age: indigenous disadvantage and the intersecting of paternalism and neo-liberalism as a racial project. Ethnic and Racial Studies: 1-20.

Madigan M (2016) Kids caught in middle of a war zone. The Courier Mail, Brisbane, 28th May.

McKenna K (2016a) End violence in Aurukun, plead women. The Courier Mail, Brisbane, 13th May.

McKenna K (2016b) School evacuated. The Courier Mail, Brisbane, 11th May.

McKenna K (2016c) Teachers evacuate after safety fears. Cairns Post, Cairns, 11th May.

Michael P (2016) RIVERS OF GROG, DESPAIR. The Courier Mail, Brisbane, 29th May.

Poynting S and Noble G (2003) 'Dog-Whistle' Journalism and Muslim Australians Since 2001. Media International Australia incorporating Culture and Policy 109: 41-49.

Poynting S, Noble G and Tabar P (2001) Middle Eastern Appearances: 'Ethnic Gangs', Moral Panic and Media Framing. The Australian and New Zealand Journal of Criminology 34(1): 67-90.

Radke B (2016) Mayor doesn't pull his punches. Cairns Post, Cairns, 14th May.

Sercombe $H$ (1995) The face of the criminal is aboriginal: Representations of aboriginal young people in the West Australian newspaper. Journal of Australian Studies 19(43): 76-94. 
Slater L (2008) 'Aurukun, we're happy, strong people': Aurukun kids projecting life into bad headlines. Borderlands E-Journal: new spaces in the humanities 7(2): 1-14.

Slater L (2010) 'Calling our Spirits Home' Indigenous Cultural Festivals and the Making of a Good life. Cultural Studies Review 16(1): 143-154.

Smyth C (2011) Special Measures in Indigenous Welfare Reform: Examining the Cape York Trial. Indigenous Law Bulletin 7(27): 12-19.

Storr C (2009) The Aurukun rape case, Indigenous sentencing and the normalisation of disadvantage. Australian Indigenous Law Review 13(1): 107-113.

Teo P (2000) Racism in the news: a Critical Discourse Analysis of news reporting in two Australian newspapers. Discourse \& Society 11(1): 7-49.

The Courier Mail (2016) Staff safety must come first. Brisbane, 11th May.

Tomlinson J (2016a) Aurukun work needs support. Cairns Post, Cairns, 14th May.

Tomlinson J (2016b) Time to stop excusing thugs. Cairns Post, Cairns, 12th May.

Vogler S and McKenna K (2016a) Cops' response under fire. The Courier Mail, Brisbane, 12th May.

Vogler S and McKenna K (2016b) Finally we are being heard. The Courier Mail, Brisbane, 14th May.

WIK WOMEN'S GROUP MOTHERS (2016) Ineptitude of police is depriving achievers. The Courier Mail, Brisbane, 26th May. 